\title{
Mexico's Community-Managed Forests as a Global Model for Sustainable Landscapes
}

\author{
DAVID BARTON BRAY, ${ }^{*}$ LETICIA MERINO-PÉREZ,$\dagger$ PATRICIA NEGREROS-CASTILLO, $\ddagger$ \\ GERARDO SEGURA-WARNHOLTZ, $₫$ JUAN MANUEL TORRES-ROJO, *** \\ AND HENRICUS F. M. VESTER † \\ *Department of Environmental Studies, Florida International University, Miami, FL 33185, U.S.A., \\ email brayd@fiu.edu \\ †Instituto de Investigaciones Sociales, Universidad Nacional Autónoma de México, Pachuca 149, Dept. 402, \\ Col. Condesa, DF 06140, México. \\ ‡Forestry Department, Iowa State University, Ames, IA 50011, U.S.A. \\ §Programa de Conservación y Manejo Forestal, Secretary of the Environment and Natural Resources (SEMARNAT), \\ Progreso No. 5., Col. Del Carmen Coyoacan, DF 04100, México. \\ **Centro de Investigación y Docencia Económica (CIDE), Carretera México-Toluca, 3655 Lomas de Santa Fe, \\ DF 01210, México. \\ ††Colegio de la Frontera Sur (ECOSUR), Mexico Carretera Chetumal-Bacalar Km. 2, Zona Industrial No. 2, \\ Chetumal, Quintana Roo 77049, México
}

\begin{abstract}
Researchers concerned with sustainable management of forests in the tropics have argued that the road to improved stewardship of forest resources is the transfer of responsibility to the local communities who get their liveliboods from them. On the other hand, conservationists have declared that the only way to stem the tide of deforestation is to place as many tracts as possible under strict protection. In this context, Mexico presents a national laboratory for studying the social and ecological benefits of delivering forests to local people. As a little-noticed result of the Mexican Revolution in the second decade of the twentieth century, well over half of the forests of Mexico were placed in community-held lands. In bistoric struggles that passed through several phases, most of these communities have now gained substantial control over the use of their forests. Because of the substantial degree of social capital in rural forms of organization in Mexico, this control of forest resources has led to an estimated 290-479 community forest enterprises (CFEs), through which communities are producing timber on their own lands. New studies are beginning to suggest that important gains in both social and economic justice, good forest management, and biodiversity protection are resulting from the actions of these CFEs. As more forests globally are being devolved to local communities, it is important to carry out more research on the Mexican model of community forest management for timber production.
\end{abstract}

Bosques Manejados Comunalmente en México como un Modelo Global de Paisajes Sostenibles

Resumen: Investigadores preocupados por el manejo sostenible de bosques en los trópicos han argumentado que el camino para una custodia mas efectiva de los recursos forestales es la transferencia de la responsabilidad a las comunidades locales que obtienen sustento de ellos. Por otro lado, conservacionistas ban declarado que la única manera de detener la ola de deforestación es colocar bajo protección estricta tantas regiones como sea posible. En este contexto, México representa un laboratorio para el estudio de los beneficios sociales y ecológicos de entregar los bosques a los habitantes locales. Como un resultado poco conocido de la Revolución Mexicana, en la segunda década del siglo veinte, más de la mitad de los bosques de México se ubicaban en tierras que estaban en manos de las comunidades. Las comunidades forestales han atravesado por distintas etapas de conflicto, tras la cuáles ban obtendio un control sustancial de los usos de sus bosques. Debido al nivel considerable de capital social en formas de organización rural en México, este control de los recursos forestales ba conducido a la integración de entre 290-479 empresas forestales comunitar-

Paper submitted December 27, 2001; revised manuscript accepted July 12, 2002.

672 
ias (EFC), en las que las comunidades están produciendo madera en sus propias tierras. Nuevos estudios están comenzando a sugerir que se están produciendo ganancias importantes en las acciones de estas EFC están generando beneficios importantes, tanto en lo que se refiere a justicia social como económica, la administración correcta de bosques y la protección de la biodiversidad. A medida en que se deleguen mayores extensiones de bosques a comunidades locales, es importante llevar a cabo más investigación sobre el modelo mexicano de manejo comunitario de bosques para la producción de forestal maderable.

\section{Introduction}

For years, researchers concerned with sustainable management of forests in the tropics have argued that the road to improved stewardship of forest resources is the transfer of varying degrees of responsibility to the local communities who get their livelihood from them. Inspired by this hypothesis, various joint-management, extractive-reserve, and indigenous-reserve projects, in which governments and local communities share responsibility for a given forest resource for production of both timber and nontimber forest products and under varying land-tenure arrangements, are increasingly gaining ground throughout the tropics (Poffenberger \& McGean 1996; Sundar 2000; Becker \& León 2000; Schwartzman et al. 2000; Stone \& D'Andrea 2001). At the same time, conservationists who despair at the steady loss of tropical forests declare that the only way to stem the tide of deforestation is to place as many tracts as possible under strict protection (Kramer et al. 1997; Bruner et al. 2001).

In this context, the country of Mexico presents a virtually unique case: much of the nation's forests were placed in the hands of communities, in successive degrees of actual control, beginning in the early decades of the twentieth century as a little-noticed result of the Mexican Revolution. Today, Mexico's common-property, community-managed forests, in both temperate and tropical areas, appear to be at a scale and level of maturity unmatched anywhere in the world. It is thus a national laboratory for studying the social and ecological benefits of delivering control of forests to local communities. A particular feature of the experiment is that, at different periods, both government and nongovernmental organizations have invested resources in promoting community-based enterprises for the production of timber. An ongoing review of the impacts of Mexican community forest management supported by the Ford and Hewlett Foundations, in which we are involved, is beginning to reveal what this national experiment says about the potential for forested landscapes to deliver both a range of ecological services and a dependable source of income for poor, rural communities. This is a preliminary report on a multifaceted research project with detailed case studies on ecological and financial sustainability and quantitative national surveys of the economic and ecological impact of Mexican community forestry.

\section{Magnitude, History, and Significance of Community Forestry in Mexico}

It has been estimated that as much as $\mathbf{8 0 \%}$ of Mexico's forests are in the hands of communities with collective land grants (in two categories known respectively as eji$d o s$ and indigenous communities). The $80 \%$ figure was first put forth by the official Mexican statistical agency and has been in use for the last 20 years, although its empirical basis is not documented. One of the authors is currently working with the Mexican National Ecology Institute (INE) on a new and better-documented estimate of the amount of forests on community lands. In the meantime, it is known that approximately half of the national territory of Mexico is in ejidos and indigenous communities (Instituto Nacional de Estadística, Geografía e Informática 1998). According to official figures, temperate and tropical forests occupy $40.1 \%$ of the national territory, a total of 56.8 million ha (Secretaría de Agricultura y Recursos Hidraúlicos 1994). Given that in earlier decades many ejidos were given remote, forested lands that were considered of little value, the circumstantial evidence suggests that well over half of Mexico's forests are on community lands.

For most of the twentieth century, Mexican communities had only putative claims to the forests on their lands because the government still claimed rights to the disposition of forest resources, giving them in logging concessions to private companies and state-owned enterprises. In the mid-1970s, however, reformists in the government forestry agency, combined with grassroots mobilizations aided by university-trained rural activists, helped focus government policy and community organizing on the potential for community management of forests for the commercial production of timber (Bray \& Wexler 1996).

In most less-developed countries, community forest management normally means management for nontimber forest products or community woodlots for domestic use on government lands (Arnold 1998). What is unique about the Mexican case is the large number of communities that are managing common-property forests for the commercial production of timber, as well as finished timber products in some cases, in industrial processes that are thought to be beyond the reach of most poor, rural communities. This "focus on stakeholders in a common property resource responding to larger mar- 
ket opportunities as an alternative source of benefits provided by the common property asset" is almost entirely absent from the literature (Antinori 2000:1). At the same time, some of the community forest enterprises (CFEs) are showing a capacity to make the transition to more competitive international markets while taking new measures to maintain forest productivity, biodiversity, and forest cover in their communities.

The rise of this globally significant sector is the result of combinations of Mexican forestry policies, a tradition of rural activism, and the social capital embedded in Mexico's traditional rural communities. Before the mid1970 s, Mexican forestry policy wavered between ineffective logging bans and concession to timber parastatals. Since the mid-1970s, a period of strong support for community forestry (1974-1986) was followed by a period of indifference and even hostility (1986-1994) (Tellez Kuenzler 1994; Bray \& Wexler 1996; Wexler \& Bray 1996). Under Mexican environment secretary Julia Carabias (1994-2000), procommunity forestry programs were once again instituted, and a new forestry law was passed in 1997 with new provisions for community forestry (de Ita 1996). But policy has not been the only crucial factor. Mexico's agrarian reform process throughout the twentieth century has created a vast rural sector of communities who govern themselves, with varying degrees of village-level democracy, under the ejido and indigenous community systems. Combined with older forms of traditional governance in many indigenous communities, this has created a capacity for self-organization and an ability to respond to outside organizing efforts (Fox 1995, 1996). This matrix of social capital in Mexico has contributed to the rise of CFEs in a world where community enterprises of any kind are an exceedingly rare commodity (Salafsky et al. 2001a).

Today, there is still no consensus on how many of Mexico's forest communities are actively managing their forests, as opposed to those many forest communities who still directly sell their timber to loggers with little supervision, with the probable result of ongoing forest degradation. One component of the current project will attempt to produce a national database of communities with logging permits. It is known, however, that more or less successful experiences are numerous in both temperate pine and oak forests and the much more silviculturally and ecologically challenging setting of tropical forests. Current estimates range from 290 to 479 CFEs at various levels of consolidation and sustainability, most of them operating since at least the 1980s (Alatorre 2000). These numbers are significant because no other country in the world appears to have anything approaching this number of communities managing their forests for the commercial production of timber. In the mid-1990s, there were only a scattering of CFEs outside of Mexico and a substantial sector of indigenous forestry in the United States (Bray \& Irvine 1993; Institute for Environ- mental Studies 1995). A global review of managed common-property forests mentions no cases of CFEs for timber other than those in Mexico (Arnold 1998).

Although the Forest Stewardship Council does not currently classify its global list of certified operations by land-tenure type, an examination of the list suggests that no other country approaches the number of certified communities that Mexico exhibits (Forest Stewardship Council 2002). There are, however, clusters of emerging CFEs for which the Mexican experience provides a major model. A small number of community forest concessions in the Petén of Guatemala have been partially modeled on the Mexican experience (Gretzinger 1998). Community timber production is also emerging in Peru and Brazil, with an estimated 16 CFEs in the Brazilian Amazon (Loayza Villegas \& Chota Valera 1996; d'Oliveira et al. 1998; S. Stone, personal communication). The number of indigenous timber management projects in Bolivia has expanded from 9 to 32 from 1999 to 2002 (P. Cronkleton. 2002. Collaboration and adaptation in the marketing of timber by indigenous peoples in lowland Bolivia. Paper presented at the conference on Working forests in the tropics: conservation through sustainable management. University of Florida, Gainesville). Salafasky et al. (2001a, 2001b) identify several additional CFEs worldwide.

\section{Financial Sustainability and Markets}

Sustainable landscapes will depend on relatively lowimpact extractive activities that are also financially sustainable, and studies have been carried out and are underway to determine the financial health of Mexican CFEs. The transition from concession logging to community logging initially meant significant gains in equity. Whereas in the pre-CFE period almost all profits flowed outside the community, in the post-CFE period communities have been able to generate significant new employment within the communities and use profits to invest in the enterprise and to build community assets ( such as potable-water networks, schools, clinics, public buildings, and social service safety nets in the form of free medical care and old-age pensions, virtually unheard of in rural Mexico) and fulfill functions left unattended by government (Merino 1997b; Alatorre 2000). The successful communities also provide good accountability and a fair distribution of forest benefits, restrict access to the forests, and invest in good forest management (Klooster 2000).

A handful of CFEs are internationally competitive, vertically integrating into sawmills and furniture and moldings workshops, particularly notable considering that they compete in the North American Free Trade Agreement with the world timber giants of the United States and Canada. The community of El Balcón on the Pacific 
Coast north of Acapulco, with $60 \%$ of its 25,565 ha in forest uses, has established a successful commercial relationship with U.S.-based Westwood Forest Products. Westwood Forest is currently urging El Balcón to certify their forest operation (a "green seal") as sustainable in order to meet new demands for certified timber products in the United States. The El Balcón CFE also generates around 250 full- and part-time jobs for both members of the community and outsiders and has fixed capital assets of over $\$ 4$ million, not counting the natural capital of the forest. Further, the social and financial capital generated by El Balcón and other neighboring communities who are also managing their forests has brought relative social peace into a region wracked by political and drug-related violence, some of it associated with illegal logging (D.B.B. \& L.M.-P., unpublished data). The community of San Juan Nuevo Parangaricutiro in Michoacan, with 18,319 ha of pine and oak forests and certified by the Forest Stewardship Council, is combining community governance structures with enterprise organization in a form of indigenous Puréchepa capitalism to export molding to Home Depot and provide upscale furniture to Mexico's leading department store chains (D.B.B. \& L.M.-P., unpublished data).

But market competitiveness, the building of community assets, and good forest management are not limited to large community forest holdings. The Oaxaca community of La Trinidad, with only 805 ha of community lands, has carried out a rezoning of its land use that includes a concentration of agricultural areas and a reforestation effort in former agricultural plots now being added to the forest areas. It operates a CFE that offers part-time employment to nearly a quarter of the community, even while cutting below authorized volumes. The community of El Rosario de Xico in Veracruz has only 560 ha of forest but generates year-round employment for nearly all the 24 community members (Merino 1997b). A recent review of the financial status of 37 communitybased, environmentally linked enterprises, mostly focused on nontimber forest products, found that only seven showed a profit (Salafsky et al. 2001a). In contrast, a survey of 42 CFEs in Oaxaca found that all were profitable, at various levels of vertical integration, and most had been in existence for over a decade (Antinori 2000:167).

\section{Ecological Impacts}

But what do we know about the ecological impacts of community forest management? Can Mexican CFEs contribute to a sustainable landscape? As in other areas, there is currently little reliable national data on how many hectares are under management by communities, but the World Bank estimates that some 7 million ha of Mexican forest are "managed," and it is probable that most of this management is by communities (World Bank 1995). In the tropical state of Quintana Roo, in the 1980s, 64 communities declared over 500,000 ha to be "permanent forest areas," the first time in tropical America that communities had voluntarily declared an end to land-use change within their communities (Merino 1997a , 1997b). The percentage of Mexico's community forests that are well managed may still be relatively small, but one indicator of positive management practices is that, by March 2002, 502,656 ha in 25 communities had been certified under criteria of the Forest Stewardship Council (Ward \& Bihun 2001; Forest Stewardship Council 2002). A few existing studies suggest that the establishment of CFEs may lead to a stabilization of forest cover in the community. Despite its reduced size, satellite images of El Rosario de Xico show a significant expansion of the forest canopy from 1982 to 1993 , and the community has declared 4 ha under strict protection for the conservation of Abies bickelii, a species of endangered oyamel fir. Satellite images of communities belonging to the Zapotec-Chinantec Union (UZACHI) in Oaxaca show that the forest area has increased by 500 ha in the last 18 years as a result of community reforestation and limits on agriculture in forest areas (Alatorre 2000; Klooster 2000).

In Quintana Roo, the major center of community tropical forest management in Mexico, experience suggests that important steps toward sustainable management of tropical forests have been taken (Kiernan \& Freese 1997). Recent research suggests that sustainable forest management is impossible in the tropics because the production costs of better-protected forests will always exceed those of forests that are "mined" for their most valuable timber (Bowles et al. 1998). But this research does not consider the multiple values of forests such as nontimber forest products, environmental services, and intergenerational values that communities, as opposed to private enterprises, bring to forest management, or the very different discount rates that may be calculated for forest products. Further, some CFEs, particularly in Oaxaca, are using profits from the logging enterprise to diversify into more benign forest enterprises such as water bottling, ecotourism, and resin-tapping, with a strong participation of women in these latter activities (Secretaría de Medio Ambiente y Recursos Naturales 2000).

In the early period of CFEs, the silvicultural focus was almost entirely on sustained yields, but, responding to the impetus of both more-stringent Mexican environmental laws and community interests in preserving the multiple values of the forest, many forest communities willingly embrace the new regulations and in many cases have preceded and gone beyond them in protection measures. Some communities in the Sierra Juárez of Oaxaca consistently log well below the authorized volume in their management plans, in a stated effort to conserve the resource. Further, forest communities have consistently shown a willingness to reduce their volume of extraction when inventories indicate they may be ex- 
tracting at an unsustainable rate. In earlier periods, the Quintana Roo communities of Noh Bec and Laguna Kaná reduced their logging volume by $29 \%$ and $37 \%$, respectively, even though logging is a key source of community income, and instituted permanent sampling plots to better monitor forest dynamics. Neither community showed any interest in liquidating its forest and investing the proceeds in a more profitable economic sector, as a private enterprise would. Some communities in both the temperate and tropical zones are applying new silvicultural practices more sensitive to the maintenance of forest structure and composition.

Communities also show an increasing commitment to broader biodiversity protection. In the La Ciudad ejido in Durango, $10 \%$ of its 11,869 ha are under protection, including 153 ha with stands of Pseudotsuga menziesii. In El Balcón in 1998, the community prohibited all hunting in the community (a loss little-lamented by most people in the community, in part because their near fulltime employment in the community forest industry leaves little time for hunting). El Balcón has $15 \%$ of its total lands under complete protection. In La Trinidad, in an ancient forest area of 365 ha, the community declared $29 \%$ of it as a biodiversity protection area. In the UZACHI communities, with a total of nearly 25,000 ha of community territory, $52 \%$ has been declared protected forest by the community, 10,000 ha of it highly biodiverse and threatened cloud forest. The Quintana Roo community of Naranjal Poniente, in addition to its permanent forest area, recently declared 2000 ha next to the community as a "forest reserve" that is currently being used for scientific research and may be used for ecotourism (making $76 \%$ of its 12,620 ha dedicated to forest) and has prohibited cattle raising in the community. In addition, the selective logging carried out by the Quintana Roo communities is "benign" for both overwintering migrants and most resident bird species (Lynch \& Whigham 1995). In her study of 42 CFEs in Oaxaca, Antinori (2000:238) argues that "The positive impact of vertical integration on recent nontimber investment and production bodes well for ecosystem-management approaches in self-governing systems."

\section{Conclusions}

CFEs are not a homogenous group, and the next steps in the current research project include a geographic and conceptual mapping of the conditions of CFEs with different levels of resources and organizations. Despite the successful generation of employment in some communities, most do not reach anything approaching full employment, and migration to Mexican cities and the United States remains an increasing option for many of the younger and most educated community members (Alatorre 2000). Also, the inherent challenges of administer- ing CFEs (administrators commonly have little training or capital) mean that many CFEs stumble from crisis to crisis (Klooster 2000). Further, most Mexican communities with forestlands are still struggling under burdens of overexploitation of their forest resource. On the ecological front, concerns have been raised about the sustainability of the mahogany harvest in Quintana Roo (Snook 1998). Wildlife management is also uneven, with some forest communities prohibiting hunting while others continue to regard pumas (Felis concolor) and coyotes ( $\mathrm{Ca}$ nis latrans) as fair game. However, there are also examples throughout Mexico of communities that have taken steps to preserve their forests even if they do not have income-generating CFEs (Merino 1997a).

Nonetheless, the magnitude of the Mexican achievement in community-managed forests, and the highly significant strides toward generating income and maintaining forest cover and associated ecological services may be the exception that proves the hypothesis that communities who are given the opportunity to manage their own forest resources will play a key role in maintaining sustainable landscapes. Thus, protected areas may be only one of a suite of options for doing so, and strict conservation may not be the only road to effective protection of biodiversity (Brechin et al. 2002; Wilshusen et al. 2002). It is particularly impressive that Mexican community forestry has been able to accomplish what it has without consistent government support, which suggests that more could be done with steadier government help. In an era when timber production from natural forests is declining, wise use of policy and incentives by the Mexican government could possibly position Mexico's forest sector as a high-value provider of niche markets from sustainably managed community forests, delivering both income and biodiversity protection.

\section{Literature Cited}

Alatorre, G. 2000. La construcción de una cultura gerencial democrática en las empresas forestales comunitarias. Casa Juan Pablos, Ciudad de México.

Antinori, C. M. 2000. Vertical integration in Mexican common property forests. Ph.D. thesis. University of California, Berkeley.

Arnold, J. E. M. 1998. Managing forests as common property. Forestry paper 136. Food and Agriculture Organization, Rome.

Becker, D. D., and R. León. 2000. Indigenous forest management in the Bolivian Amazon: lessons from the Yuracaré people. Page 163192 in C. C. Gibson, M. A. McKean, and E. Ostrom, editors. People and forests: communities, institutions, and governance. MIT Press, Cambridge, Massachusetts.

Bowles, I. A., R. E. Rice, R. A. Mittermeier, and G. A. B. da Fonseca. 1998. Logging and tropical forest conservation. Science 280:1899-1900.

Bray, D. B., and D. Irvine, eds. 1993. Resource and sanctuary: indigenous peoples, ancestral rights, and the forests of the Americas. Cultural Survival Quarterly 17(1).

Bray, D. B., and M. B. Wexler. 1996. Forest policies in Mexico. Pages 217-228 in L. Randall, editor. Changing structures in Mexico: political, social, and economic prospects. M. E. Sharpe, Armonk, New York. 
Brechin, S. R., P. R. Wilshusen, C. L. Fortwangler, and P. C. West. 2002. Beyond the square wheel: toward a more comprehensive understanding of biodiversity conservation as social and political process. Society and Natural Resources 15:41-64.

Bruner, A. G., R. E. Gullison, R. E. Rice, and G. A. B. da Fonseca. 2001. Effectiveness of parks in protecting tropical biodiversity. Science 291:125-128.

de Ita, A. 1996. Política forestal: entre el bosque natural y las plantaciones forestales comerciales. Estudios Agrarios. 6:83-98.

d'Oliveira, M. V. N., E. M. Braz, D. F. R. P. Burslem, and M. D. Swaine. 1998. Small-scale natural forest management. Tropical Forest Update 8:5-7.

Forest Stewardship Council (FSC). 2002. Forests certified by FSCaccredited certification bodies. FSC, Oaxaca, Mexico. Available from http://www.fscoax.org/principal.htm (accessed March 2002).

Fox, J. 1995. Governance and rural development in Mexico: state intervention and public accountability. The Journal of Development Studies 32:1-30.

Fox, J. 1996. How does civil society thicken?: The political construction of social capital in rural Mexico. World Development 24: 1089-1103.

Gretzinger, S. P. 1998. Community forest concessions: an economic alternative for the Maya Biosphere Reserve in the Petén, Guatemala. Pages 111-124 in R. B. Primack, D. B. Bray, H. A. Galletti, and I. Ponciano, editors. Timber, tourists, and temples: conservation and development in the Maya forest of Belize, Guatemala, and Mexico. Island Press, Washington, D.C.

Institute for Environmental Studies (IES). 1995. Case studies of community-based forestry enterprises in the Americas. IES, University of Wisconsin, Madison.

Instituto Nacional de Estadística, Geografía e Informática (INEGI). 1988. Atlas ejidal nacional. INEGI, Aguascalientes, Mexico.

Kiernan, M., and C. Freese. 1997. Mexico's plan piloto forestal: the search for balance between socioeconomic and ecological sustainability. Pages 93-131 in C. Freese, editor. Harvesting wild species: implications for biodiversity. Johns Hopkins University Press, Baltimore, Maryland.

Klooster, D. 2000. Institutional choice, community, and struggle: a case study of forest co-management in Mexico. World Development 28:1-20.

Kramer, R., C. Van Schaik, and J. Johnson. 1997. Last stand: protected areas and the defense of tropical biodiversity. Oxford University Press, New York.

Loayza Villegas, M., and G. Chota Valera. 1996. An indigenous Amazonian community and its forest. Tropical Forest Update. 6:10-11.

Lynch, J. F., and D. F. Whigham. 1995. The role of habitat disturbance in the ecology of overwintering migratory birds in the Yucatan Peninsula. Pages 198-210 in M. H. Wilson and S. Sader, editors. Conservation of Neotropical migratory birds in Mexico. Miscellaneous publication 727. Maine Agricultural and Forest Experiment Station, Orono.

Merino, L. 1997a. El manejo forestal comunitario en México y sus perspectivas de sustentabilidad. Centro Regional de Investigaciones Multidisciplinarias, Universidad Nacional Autónoma de México (UNAM), Cuernavaca, México.
Merino, L. 1997b. Revaloración de la selva y manejo forestal sustentable: la experiencia de la Organización de Ejidos Forestales de la Zona Maya de Quintana Roo. Ph.D. thesis. Universidad Nacional Autónoma de México, Mexico City.

Poffenberger, M., and B. McGean. 1996. Village voices, forest choices: joint forest management in India. Oxford University Press, Calcutta.

Salafsky, N., H. Cauley, B. Balachander, B. Cordes, J. Parks, C. Margoluis, S. Bhatt, C. Encarnación, D. Russell, and R. Margoluis. 2001a. A systematic test of an enterprise strategy for communitybased biodiversity conservation. Conservation Biology 15:15851595.

Salafsky, N., M. Henderson, and M. Leighton. 2001b. Community-based timber production: a viable strategy for promoting wildlife conservation? Pages 575-594 in R. A. Fimbel, A. Grajal, and J. G. Robinson, editors. The cutting edge: conserving wildlife in logged tropical forests. Columbia University Press, New York.

Schwartzman, S., A. Moreira, and D. Nepstad. 2000. Rethinking tropical forest conservation: perils in parks. Conservation Biology 14: 1351-1357.

Secretaría de Agricultura y Recursos Hidraúlicos (SARH). 1994. Inventario nacional forestal periódico, 1992-1994. SARH, Ciudad de México.

Secretaría de Medio Ambiente y Recursos Naturales, Delegación Oaxaca (SEMARNAT). 2000. Conservación y manejo comunitario de los recursos forestales en Oaxaca. SEMARNAT, Oaxaca, México.

Snook, L. 1998. Sustaining harvests of mahogany (Swietenia macrophylla King) from Mexico's Yucatán forests: past, present and future. Pages 61-80 in R. Primack, D. Bray, H. Galletti, and I. Ponciano, editors. Timber, tourists and temples: conservation and development in the Maya forest of Belize, Guatemala, and Mexico. Island Press, Washington, D.C.

Sundar, N. 2000. Unpacking the 'joint' in joint forest management. Development and Change 31:255-279.

Stone, R. D., and D'Andrea. 2001. Tropical forests and the human spirit: journeys to the brink of hope. University of California Press, Berkeley.

Tellez Kuenzler, L. 1994. La modernización del sector agropecuario y forestal. Fondo de Cultura Económica, Ciudad de México.

Ward, J. R., and Y. Bihun. 2001. Stewardship of Mexico's community forests: expanding market and policy opportunities for conservation and rural development. Pages 145-167 in I. A. Bowles and G. T. Prickett, editors. Footprints in the jungle: natural resource industries, infrastructure, and biodiversity conservation. Oxford University Press, New York.

Wexler, M. B., and D. B. Bray. 1996. Reforming forests: from community forests to corporate forestry in Mexico. Pages 235-246 in L. Randall, editor. Reforming Mexico's agrarian reform. M.E. Sharpe, Armonk, New York.

Wilshusen, P. R., S. R. Brechin, C. L. Fortwangler, and P. C. West. 2002. Reinventing a square wheel: critique of a resurgent protection paradigm in international biodiversity conservation. Society and Natural Resources 15:17-40.

World Bank. 1995. Mexico resource conservation and forest sector review. Report 13114-ME. World Bank, Washington, D.C.

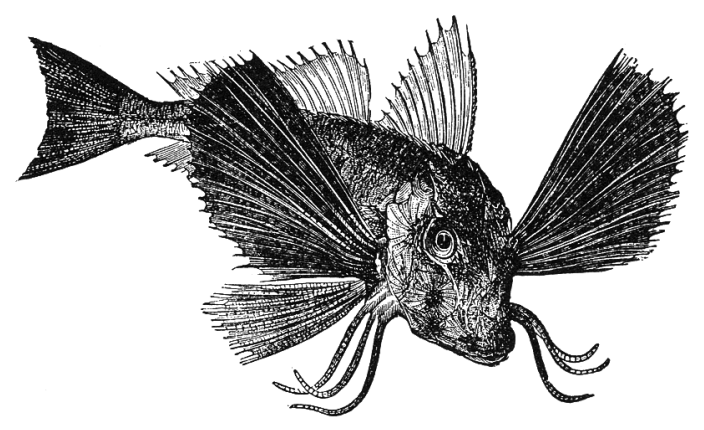

